timekeeper in the central nervous system, which might open very wide fields of investigation.

To those engaged in any of these studies, however, the main requirement of progress is a wide awareness among biologists in general of the nature and scope of the problems which age studies raise, since only through this will the additional information we need be forthcoming.

${ }^{1}$ Comfort, A., "The Biology of Senescence" (Routledge and Kegan Paul, London, 1956).

\&udzinska, M., Science, 113, 10 (1931).

${ }^{3}$ Haldane, J. B. S., "New Paths in Geneties" (London, 1941). "Medawar, P. B., "An Unsolved Problem of Biology" (H. K. Lewis,

- Bidder, G. P., Nature, 115, 495 (1925) ; Brit. Med.J., 1i, 5831 (1932).

- Gardner, G., and Hurst, H., Proc. Utah Acad. Sci., 10, 149 (1933).

'Leslie, P. H., and Ranson, R. M., J. Anim. Ecol., 9, 27 (1940).

${ }^{8}$ Leslie, P. H., Tener, J. S., Vizoso, M., and Chitty, H., Proc. Zool. Soc., Lond., 125, 115 (1955).
Oliff, W. D., J. Anim. Ecol., 22, 217 (1953).

${ }^{10}$ Kelley, R. B., Aust. Vet. J., 15, 184 (1939).

"McCay, C. M., in Lansing, A. I., "Problems of Ageing" (Williams and Wilkins Co., Baltimore, 1952).

${ }^{12}$ King, J. T., and Visscher, M. B., Fed. Proc., 9, 70 (1950).

${ }^{14}$ McCance, R. A., and Widdowson, A. M., Ciba Found. Colloq. Ageing, $1,186(1955)$.

${ }^{15}$ Sinclair, H. M., Ciba Found. Colloq. Ageing, 1, 194 (1955).

16 Tanner, J. M., "Growth at Adolescence" (Blackwell, Oxford, 1955).

${ }_{17}$ Morant, G. M., Proc. Roy. Soc., B, 137, 443 (1950).

${ }^{18}$ Jolly, H., "Sexual Precocity" (Blackwell, Oxford, 1955).

10 Beeton, M., and Pearson, K., Biometrika, 1, 50 (1901).

${ }^{\text {so }}$ Pearl, R., and Parker, S. L., Amer. Nat., 56, 174 (1922).

${ }_{21}$ Comfort, A., Nature, 172, 83 (1953).

22 Clarke, J. M., and Maynard Smith, J., J. Genet, 53, 172 (1955).

${ }^{23}$ Grüneberg, H., Nature, 173, 674 (1954).

24 McLaren, A., and Michie, D., Nature. 173, 886 (1954).

${ }_{25}$ Billingham, R. E., Brent, L., and Medawar, P. B., Nature, 172, 603 (I953).

\title{
OBITUARIES
}

\section{Dr. John Wishart}

Dr. John WIShart, reader in statistics in the University of Cambridge, was born in Perth on November 28, 1898, and was educated at Perth Academy and the University of Edinburgh, where he was one of the many able mathematicians taught by Sir Edmund Whittaker. After leaving Edinburgh he spent two years teaching at Leeds, and then went in 1924 to the Galton Laboratory at University College, London, as research assistant to Prof. Karl Pearson. He stayed there three years, and after a brief period at the Imperial College of Science and Technology, joined the staff of the Rothamsted Experimental Station in the statistical department just at the beginning of its great period of expansion under Sir Ronald Fisher's inspiring leadership. He made his mark there, and left to become reader in statistics at Cambridge in 1931. During the Second World War he served as a captain in the Intelligence Corps during 1940-42 and was a temporary assistant secretary at the Admiralty during 1942-46. He was a Fellow of the Royal Statistical Society, of the Institute of Mathematical Statistics and of the American Statistical Association, a member of the International Institute of Statistics, and an associate editor of Biometrika.

To one who was associated with him from the earliest days and in all three places where his lifework was done, the tragedy of his early death at the age of fifty-seven is only too apparent. He was drowned in a bathing accident in Mexico on July 14, during a visit to Central America on behalf of the United Nations Food and Agriculture Organization, to organize a research centre for the teaching of statistics in agricultural research.

Wishart was the author of three books on field experimentation and many research papers on mathematical statistics in scientific journals. His scientific work was characterized by exceptional accuracy and attention to detail, with which he combined more than usual organizing ability. The first of these characteristics was shown in his earliest papers on the numerical computation of certain integrals; the second became manifest at Rothamsted, where he helped with the organization of field experimental programmes and for several years carried out most of the statistical analysis. His bestknown paper, produced at Rothamsted, was concerned with what came to be known as the 'Wishart distribution'. This is the generalized product moment distribution in samples from a multivariate normal population. Another of his main theoretical interests was the development of explicit formulæ for the cumulants of ' $k$ statistics' using Fisher's combinatorial methods. This subject formed an important part of the lectures which he gave at Cambridge, and he returned to it as late as 1952 .

Wishart was at his best in the years 1931-39, when as a result of his teaching at Cambridge, the modern statistical outlook was adopted by a number of Cambridge mathematicians who took up statistics as a career. They spread the knowledge of statistics as a scientific subject and did much to set up a chain-reaction which still continues. Their training made them aware of the almost unlimited potentialities of statistical methods in many diverse fields, and there is still no sign of diminishing tempo in their application.

J. O. IRWIN

\section{Prof. E. A. Braude}

By the sudden and untimely death on July 23 of Prof. E. A. Braude we have lost one of the most brilliant and most active of our younger organic chemists.

Ernest Braude was born in Germany in 1922, came to Britain as a boy of fifteen, and was naturalized at the age of twenty-four. His British education started in private schools and at Farnham Grammar School. He spent one year at Birkbeck College before going to the Imperial College of Science and Technology, where he spent virtually the rest of his academic life. He graduated with first-class honours in chemistry in 1942, receiving the Acland and Frank Hatton Prizes. He spent the next three year's as research assistant to Sir Ian Heilbron, became an assistant lecturer in organic chemistry in 1946, lecturer in 1947 and reader in 1952. He succeeded to the chair of organic chemistry in 1955 . In 1950 he receiver the Meldola Medal of the Royal Institute of Chemistry and the D.Sc. of the University of London.

Braude published his first original papers at the age of twenty-two, and in the next twelve years, up to the time of his death, a flow of research memoirs followed, remarkable both in quantity and in the very high standard maintained. In his earlier years he worked in collaboration particularly with Dr. (now Prof.) E. R. H. Jones, and more recently, in 